\title{
UNRRA a uprchlická krize po druhé světové válce. Operace „Displaced persons“
}

\author{
JANA FRYDRYŠKOVÁ YASIN*
}

UNRRA and the Displaced Persons Operation after WWII

\begin{abstract}
This paper is dedicated to the UNRRA, the United Nations organization envisioned to deal with the expected consequences of ongoing war including devastation, famine, diseases and mass displacement. As it turned out, tackling the mass displacement was most important and challenging task of UNRRA. Expectations were set high. However, lack of comprehension of challenges raised doubts about UNRRA and its role in whole postwar rehabilitation process. Questions were raised about size and cost of administrative staff, and about their reliability and effectiveness. Did UNRRA had sufficient "know-how" to carry out relief work at global scale? The study of archive material, memoirs and specialized bibliography, and various published articles helps to uncover the reasons behind huge criticism faced by UNRRA.
\end{abstract}

Keywords: displacement; internacionalism; postwar reconstruction process; resocialization; humanitarianism

DOI: $10.14712 / 23363525.2018 .50$

\section{Úvod}

Rok 2015 je znamením eskalace jednoho z největších a nejhůře řešitelných problémů dnešní civilizace - migrační krize. Tato politická krize je výsledkem dlouhotrvajících válečných a politických konfliktů, ekonomických krizí, demografických změn, populační exploze a v neposlední řadě souvisí i s následky přírodních katastrof. V roce 2015 přišlo do Evropy odhadem na 1,3 milionu lidí a tato událost se stala na dlouho hlavním mediálním tématem. Často se o této krizi mluvilo jako o nejhorší uprchlické krizi od druhé světové války. Detailnější informace však o tom, jak probíhalo a koho se hlavně týkalo masové přesídlování po konci druhé světové války, zůstaly skryty.

Článek se snaží poukázat na jeden $\mathrm{z}$ aspektů humanitární pomoci v době její rané institucionalizace - na organizaci akce „displaced persons“ pod záštitou nově vzniklé mezinárodní organizace UNRRA. Navzdory všem možným přípravám, diplomatickým jednáním a velké podpoře se jednalo o velmi složitý a v začátcích i dosti chaotický proces. Jak odpưrci organizace UNRRA, tak i její podporovatelé se vesměs shodli na bezprecedentnosti situace a podmínek, které jsou v pozadí vzniku samotné organizace, jež byla mnohými brána jako experiment na poli mezinárodní spolupráce. Na jedné straně zaznívaly nadšené argumenty vztahující se k zakládající smlouvě organizace (v roce 1943) coby k jednomu z nejdůležitějších válečných politických rozhodnutí. Dle některých politiků vznikla organizace, která se měla stát rovněž jakousi platformou pro světový management [Reinisch 2011]. Na straně

\footnotetext{
Mgr. Jana Frydryšková Yasin, Ústav hospodářských a sociálních dějin, Filozofická fakulta, Univerzita Karlova, Celetná 20, 11642 Praha 1. E-mail: J.Frydryskova@seznam.cz.
} 
druhé zůstaly nezodpovězeny otázky týkající se nadměrných výdajů v poměru s výsledky činnosti organizace. Faktem ale zůstává, že jak zaměstnanci a úředníci z řad organizace, tak především samotní uprchlíci se museli vyrovnat se změnou politické atmosféry v rámci nastupující studené války. V průběhu celé akce se měnilo politické, etnické i sociální složení migračních skupin, stejně tak i důvod pobytu v uprchlickém centru. Nejdříve se jednalo o osvobozené vězně koncentračních táborů, totálně nasazené, válečné zajatce, tedy vše oběti nacistického režimu. Později se obyvateli uprchlických center a tzv. tvrdým jádrem nerepatriovatelných stávali zejména lidé, kteři odcházeli kvůli hrozícímu komunistickému útlaku ve svých domovinách, či se z podobného důvodu nechtěli do svých domovů vrátit. Tato zbylá centra, rozesetá zejména po Bavorsku, nebyla tak již mementem konce světové války, ale součástí nově vzniklého západního Německa.

Ochladnutí vztahů mezi Západem a Východem se promítlo do všech možných oblastí uprchlické krize, podpora veřejnosti i politiků sponzorujících zemí klesala, repatriační řízení se značně komplikovala a celá akce DPs se v poměru k ostatním úsekům organizace, zejména těm rehabilitačním, rapidně prodražovala. ${ }^{1} \mathrm{~V}$ době okolo roku 1947 procesy repatriačních řízení prakticky ustaly a nastala doba vyjednávání ohledně možných přesídlovacích programů. Tento proces byl již v pravomoci nově ustanovené IRO - Organizace na podporu uprchlíků, nebot dočasně ustanovená organizace UNRRA končila svou činnost. Na základě vzpomínek, archivních materiálů a zahraničních prací se snažím odkrýt "mentální mapu“ prvních oficiálních humanitárních pracovníků, stejně jako obyvatelů uprchlických center.

Česká historiografická produkce se tímto tématem zabývala spíše okrajově a pojímala jej hlavně jako součást problematiky totálně nasazených či po válce vysídlených občanů. ${ }^{2}$ Až Jaroslav Vaculík, který se od 90. let zabývá tématem reemigrace a repatriace československých občanů, na toto téma vydal několik studií [Vaculík 2002, 2003]. Ze zahraničních publikací mají význam pro toto téma zejména práce Gerarda Daniela Cohena [2011], Adama R. Seippa [2013], dílo S. Gemieho, F. Reidové a L. Humberta [2012], studiem osudů židovských vězňů po skončení války se zabýval Arieh J. Kochavi [2001] či Zeev W. Mankowitz [2002]. Z německé historiografie bych zmínila práci historika Andrea Kosserta [2009], který se zabýval osudem odsunutých Němců v Německu.

Dokumenty, zachycující z perspektivy organizace UNRRA tuto poválečnou historii, jsou uchovány kromě hlavního archivu OSN v New Yorku také v německých archivech, zejména pak v centrálním Bundesarchiv v Koblenzi, v mnichovském Hauptstaatsarchiv, a mnoho cenného materiálu z organizace UNRRA vztahujícímu se k otázce DP je uloženo v Národním archivu v Praze na Chodovci. Fond týkající se organizace UNRRA je tu velmi bohatý a přehledný, což svědčí o velice dobré organizaci Mise UNRRA v ČSR a Československého úřadu pro hospodářskou pomoc a obnovu. Jsou zde uloženy i průvodní dokumenty zachycující politická a diplomatická jednání při vzniku celé struktury organizace, jednání v průběhu ustanovení rezolucí, dokumenty objasňující repatriační mechanismy, atd. Jsou zde také celé kopie původních účetních materiálů, statistik použitých oficiálním

\footnotetext{
Program DP v Německu převyšoval obdobný program v Číně až trřikrát a měl nejvíce zaměstnanců ze všech jednotek celé organizace (viz kapitola Zaměstnanci organizace) [Woodbridge 1950: 428].

2 Viz např. [Mainuš 1974], [Kuklík 2002], [Křen 1969], [Moulis 1993]. Organizaci UNRRA na našem území se věnoval historik Karel Sommer [1993].
} 
historikem Georgem Woodbridgem, ${ }^{3}$ který byl zaměstnán v ústředí organizace v Londýně a později v roce 1950 vydal obsáhlou třídílnou monografii UNRRA: The History of the United Nations Relief and Rehabilitation Administration. Celkově tento fond tvoří materiály jedinečné hodnoty z oblasti poválečného politického a ekonomického vývoje ČSR a potažmo celé Evropy. Za zmínku stojí také dobová žurnalistika. Všechna významná tehdejší periodika se věnovala s různými časovými intervaly i organizaci UNRRA, repatriačním řízením, hledání ve válce ztracených dětí atd. V neposlední řadě jsou neméně důležitým a hodnotným pramenným materiálem dobová svědectví ve vydaných pamětech či denících. ${ }^{4}$

\section{Konec války - masové vysídlení}

Americký prezident Franklin D. Roosevelt vizionářsky předpověděl v ř́ijnu roku 1939 humanitární krizi, když pronesl: „[Až] tato strašná válka skončí, [ve světě] budou ne milion ale deset nebo dvacet milionů mužů, žen a dětí mnoha ras, náboženství, z mnoha států a možná i z několika kontinentů, kteří vytvoři široký obraz uprchlictví. " ${ }^{5}$ Roosevelt již v této době předpověděl jak rozdílné řešení tohoto geopolitického a ekonomického problému, tak i jeho rozsah, který převyšoval do té doby veškeré podobné zkušenosti. Čím více se stávala válka součástí každodenního života v pozdějších letech, tím více bylo zřejmé, že se bude jednat o prakticky úplně nový historický rozměr.

Bylo předvídatelné, že většina $\mathrm{z}$ těchto lidí se bude chtít dostat za každou cenu co nejdřive domů, a to i přes stále trvající boje. Správně se předpokládalo, že takové velké neorganizované přesouvání mas lidí by mohlo zasáhnout do samotných osvobozovacích bojů, mohlo by napomoci k šiřrení nemocí a v neposlední řadě by mohl nastat sociální a ekonomický chaos. Vedoucí političtí i armádní představitelé spojeneckých sil si uvědomovali potřebu a naléhavost začít tento problém řešit organizovaně kvůli zajištění dodávek jídla, provizorního ubytování, základní zdravotní péče a speciálních transferů. Uprchlický problém se v roce 1945 týkal nejen Evropy, ale i Blízkého a Dálného východu.

Organizace UNRRA byla první organizací zabývajících se otázkou masového uprchlictví a přesídlení. Vedle její hlavní činnosti v oblasti dodávek pro obnovu a rehabilitaci pomáhala organizovat shromažd’ovací centra a repatriaci jejich obyvatel, tzv. „displaced persons“. Pod anglickým všeobecně uznávaným termínem „displaced persons“ (zkratka DPs) se skrývá v češtině mnoho výrazů od válečných uprchlíků, lidí během války nuceně přemístěných, zavlečených, nasazených a ztracených až po bývalé obyvatele koncentračních táborů, vězně atd. V roce 1943 bylo odhadováno, že v celé válečné Evropě bylo až na 21 miliónů těchto lidí [Woodbridge 1950: 469]. Na konci války se pak předpokládalo, že jenom v Německu existovalo na 8 miliónů lidí, kteří se mohli kvalifikovat jako DPs

3 George Woodbridge pomáhal americké vládě již při programu Lend-Lease, následně, po skončení organizace UNRRA, byl vládním historikem až do roku 1953, kdy odešel do Londýna. Tam pomáhal při realizaci Marshallova plánu.

4 Viz např. [Hilton 2006], [Klemperer 2000, 2004] nebo z pohledu zaměstnance organizace UNRRA: Doherty [2000].

5 Franklin D. Roosevelt [October 17, 1939], Address at the Meeting of the Officers of the Intergovernmental Committee on Political Refugees, Public Papers of the Presidents of the United States. Dostupné z: <http:// www.presidency.ucsb.edu/ws/index.php?pid=15826\&st=\&st1> [15. 11. 2016]. 
dle kritérií organizace UNRRA a spojeneckých armád. ${ }^{6}$ Další se nacházeli v desítkách tisíc v Rakousku, Itálii, na Blízkém a Středním východě. Z celkového počtu se organizaci v kooperaci s armádami spojenců a správních představitelů zón podařilo navrátit podstatnou část lidí DPs do zemí jejich původu. ${ }^{7}$ Toto byla první fáze celého problému poválečných uprchlíků, která se hodnotila z hlediska logistiky, rychlosti a efektivity jako úspěšná. Na začátku roku 1946, nastala druhá, složitější fáze zahrnující repatriaci a přemístění zbývající části exulantů, kterých bylo dle hrubých odhadů okolo 1,5 miliónů. Většina $\mathrm{z}$ nich pobývala v kempech na německém území (1,2 mil.), menší část v Rakousku a Itálii. Část z nich odmítala repatriaci na základě osobních, politických, ekonomických či psychologických důvodů. Další skupiny lidí se považovaly, co se týče příslušnosti ke státu, za zcela bezprizorní. UNRRA na začátku své působnosti nepředpokládala takové výrazné množství lidí odmítající se vrátit do zemí původu (zejména do zemí, jež začaly spadat do sféry sovětského vlivu). Někdy v polovině roku 1946, kdy si organizace začala uvědomovat, že bude určitě množství lidí nemožné donutit k repatriaci, se začalo jednat o tzv. resettlement (přemístění) z center, které byly nevyhovující pro dlouhodobý pobyt, do různých zemí. V návaznosti na přesídlení se UNRRA začala zajímat o možné pracovní uplatnění a směřovala rehabilitaci lidí v centrech tímto směrem. V̌̌e se řešilo paralelně také už na úrovni nově vytvořeného Výboru pro uprchlíky při OSN (který předcházel pozdější plánované IRO), kam byla UNRRA pozvána jako pozorovatelský orgán.

To, že UNRRA bude tou organizací, která bude pomáhat při repatriacích a organizaci samotné pomoci všem „displaced persons“, bylo přijato již v základní smlouvě, kde se členské státy dohodly na organizaci návratu těchto lidí. Jakmile tato role organizace byla potvrzena, nastaly samozřejmé otázky. Jak, kdy, jaké budou přesně kompetence organizace UNRRA, které osoby budou přicházet v úvahu pro tuto pomoc. Při přípravě vše vypadalo na hladký a organizovaný chod, ale v průběhu a ke konci této rozsáhlé „akce“ bylo jasné, že žádná z jiných dalších operací organizace UNRRA nebyla obestřena tolika zmatky a žádné jiné se nedostalo tolika publicity, pozornosti a individuálních iniciativ. ${ }^{8}$

\section{Příprava a struktura akce DP}

Problémem uprchlictví se zabývala Rada organizace hned na prvním zasedání a bylo bez větších připomínek doporučeno se ke konci války zaměřit na smlouvy s jednotlivými vládami či vojenskými autoritami a začít zabezpečovat repatriaci všech zavlečených osob, které byly v nuceném exilu a jejichž návrat byl urgentně žádoucí. ${ }^{9}$

6 Národní archiv (dále jen NA), fond UNRRA (dále jen UNRRA), karton 53, zahraniční obchodní tisk, The Story of UNRRA, February 15, 1948, s. 35.

7 Počty se liší, hrubý odhad je něco přes 6000000 úspěšných repatriantů [Cohen 2012].

8 Tento typ poválečné pomoci vyžadoval finance zejména pro dva účely: tzv. operating costs (zásilky a služby) a administrative costs. V̌̌ichni členové organizace přispívali na administrativní účely, pouze však ty státy, které nebyly okupovány, přispívaly i na nákup dodávek a financování služeb. Největší podíl z této skupiny měly USA. Kongres USA již v roce 1943 uvolnil prostředky v hodnotě 1,35 mld. dolarů, přičemž se celý rozpočet jen v prvním roce pohyboval okolo 1,8 mld. dolarů, NA, fond Ministerstva zahraničních věcí - výstřiž̌kový archiv (dále jen MZV-VA), karton 1025, výroční článek Dvě léta mezinárodní organizace proti hladu, Právo lidu, 9. 11. 1945.

9 NA, UNRRA, karton č. 53, zahraniční obchodní tisk, A Compilation of Resolutions on Policy, First and Second Session of UNRRA Council, resolution no. 10, 47, 48. 
S blížícím se koncem války byly ustanoveny první divize a komise pro organizaci uprchlíků ve Washingtonu a Londýně. Stejně tak jako ostatní divize UNRRA, ani tyto divize neměly v roce 1944, kdy většina Evropy byla dosud pod kontrolou Německa, ještě šanci začít praktickou činnost jejich náplně. UNRRA navíc neměla žádný přístup k vojenským materiálům, a tak tyto komise na začátku trpěly velkým nedostatkem informací, jak, kde, u koho začít, a pokud už nějaké informace získaly, tak v nich převládal naprostý chaos, což zdržovalo plánování i samotný start akce. ${ }^{10}$ Největší bezmoc pocitovali lidé, kterých se to týkalo nejvíce - samotní zavlečení, osvobození z koncentračních táborů, pomoc byla totiž zdlouhavá a neorganizovaná, podmínky v táborech katastrofální. Celá věc se začala řešit na nejvyšších místech, když na žádost prezidenta Trumana popsal své zážitky Earl. G. Harrison, vysoký státní úředník. Ve svém slavném „Harrison Report“ poukázal na chaos, který na jaře a v létě roku 1945 panoval v táborech, kde se soustřed’ovali uprchlíci a bývalí vězňové $z$ koncentračních táborů. Obvinil jak spojenecké armády, tak částečně i organizaci UNRRA z neschopnosti, z neadekvátní spolupráce a prodlužování utrpení hlavně židovských obyvatel DP táborů. Popisoval, že i přes veškeré nadšení pomáhat, je UNRRA naprosto nepřipravena, nevybavena, kritizoval organizaci za špatný výběr personálu, který $\mathrm{v}$ častých př́padech neuměl dostatečně komunikovat $\mathrm{v}$ angličtině a nebyl tak schopen relevantní spolupráce s představiteli spojeneckých armád. ${ }^{11}$ Přes veškerou kritiku ale podpořil záměr, aby organizace akce „displaced persons“ byla i nadále v kompetenci organizace UNRRA, které se měly dle něj rozšírit pravomoce, aby byla v budoucnu schopna spolupracovat na nejvyšší politické úrovni se správními představiteli zón v Německu, Rakousku a s vládami zemí, kterých se problém DPs týkal. Prezident H. Truman se následně obrátil na vedoucího armádního velitele americké okupační zóny v Německu, což byl v té době samotný generál Eisenhower, a žádal ho o co nejrychlejší nápravu a zlepšení podmínek táborů byt i na úkor německých obyvatel.

Situace se následně začala opravdu zlepšovat a problémy se začaly řešit organizovaněji. Již na prvním zasedání Rady se rozhodlo o kontaktování a navázání oficiálního styku s vojenskými představiteli okupačních zón v Německu a Rakousku. Navzdory nutnosti zefektivnit a zrychlit rozjíždějící se pomoc zasaženým osobám napříč kontinentální Evropou se nicméně tato jednání protáhla a rozhodnutí bylo učiněno až na třetím zasedání Rady UNRRA v srpnu 1945. Debata se protáhla i díky prvním neshodám mezi zástupci USA a slovanských států. UNRRA také neměla ambici být plně neutrální, měla jasné dané limity. Chtěla pomoci pouze obětem nacismu a fašismu, ale již ne samotným obyvatelům či vojákům nepřítele. Slovanské členské státy byly navíc proti tomu, aby se pomáhalo lidem, kteří se brání repatriaci. Otázka a definice oběti se stala předmětem sporu a důvodem dalšího zdržení v jednání [Woodbridge 1950: 486]. Po prvotních neshodách byla nakonec na tomto zasedání přijata definice „displaced persons“ spolu se dvěma zásadními rozhodnutími:

1) Péče nakonec mohla být poskytnuta i bez smlouvy se zemí původu dotyčného.

2) Správa UNRRA byla pověřena připravit smlouvy se čtyřmi mocnostmi kontrolující rozdělené zóny v Německu a Rakousku ohledně péče a transportu „displaced persons“.

10 NA, UNRRA, karton 55, The Journal Third Session of the Council, s. 86.

11 Celý text Harrisonova reportu lze najít např. na stránkách Muzea holocaustu zde: <https://www.ushmm.org /exhibition/displaced-persons/resourc1.htm> [5. 12. 2016]. 
Náklady na péči, prostředky a transport neměly být hrazeny z rozpočtu Správy UNRRA, ale na návrh delegace USA měly být tyto náklady závazkem německé ekonomiky.

Smlouvy s okupujícími mocnostmi byly uzavřeny v tomto pořadí: 27. listopadu 1945 s britskou správou, 18. února $1946 \mathrm{~s}$ francouzskou správou a nakonec o jeden den později s americkou.

Smlouvy přerozdělily odpovědnost následovně:

1. Odpovědnost vojenských představitelů mocností [Woodbridge 1950: 488]

a) Plná odpovědnost za všechny základní dodávky.

b) Koordinace pohybu, plány a zajištění transportu prostředků potřebných na repatriaci.

c) Zajištění bezpečnosti a veřejného pořádku.

2. Odpovědnost organizace UNRRA

a) Vnitřní správa shromaždujících a ubytovacích center DPs.

b) Dozor a koordinace dobrovolníků pracující v těchto centrech.

c) Obstarání nadstandardních požitkových dodávek jako např. tabák, cigarety, holicí strojky, dětské sladkosti, rekreační vybavení a materiál na vzdělávání.

d) Řizení tzv. CTB (Central Tracing Bureau) - Centrálního pátracího úřadu.

e) Spolupráce s vojenskými a vládními autoritami při zařizování repatriací včetně recepce lidí v rodné zemi.

\section{Zaměstnanci organizace}

V této počáteční fázi se UNRRA zaměřila zejména na výběr vhodných zaměstnanců. Poměr lidí určených pro správu programu „displaced persons“ vưči ostatním, kteří měli na starosti zásilky a jejich distribuci, byl velmi výrazný, jak ukazuje následující tabulka.

Zaměstnanci Class I. K 30. 9. $1946^{12}$

\begin{tabular}{|l|r|l|r|}
\hline \multicolumn{2}{|l|}{ administrativní pracovníci } & \multicolumn{2}{l|}{ operační pracovníci } \\
\hline Ústř̌edí, Washington & 1527 & operace displaced persons, Německo & 4160 \\
\hline Evropská regionální kancelář & 1437 & AFHQ, styčná kancelář, Rím & 18 \\
\hline Jihozápadní Pacifik, kancelář & 61 & Albánská mise & 42 \\
\hline Nový Zéland, kanceláŕ & 3 & Rakouská mise & 547 \\
\hline Styčná kancelář, Ženeva & 2 & Belgická mise & 11 \\
\hline Manila, zásobovací kanceláŕ & 12 & Běloruská mise & 13 \\
\hline Argentina, zásobovací mise & 1 & Čínská mise & 1354 \\
\hline Brazílie, zásobovací mise & 2 & Československá mise & 40 \\
\hline Chile, zásobovací mise & 3 & Dánská mise & 3 \\
\hline Kuba, zásobovací mise & 2 & Dodekánské ostrovy, mise & 26 \\
\hline
\end{tabular}

12 NA, UNRRA, karton 56, zahraničně obchodní tisk, inv. č. 119, Report of the Director General to the Council for the period 1st July to the 30th September, s. 87. 


\begin{tabular}{|c|c|c|c|}
\hline Mexiko, zásobovací mise & 3 & Etiopská mise & 18 \\
\hline New Delhi, Indie, zásobovací mise & 3 & Finská mise & 4 \\
\hline Uruguay, zásobovací mise & 2 & Francouzská mise & 123 \\
\hline Venezuela, zásobovací mise & 2 & Řecká mise & 347 \\
\hline Celkem & 3060 & Mad’arská mise & 10 \\
\hline & & Italská mise & 535 \\
\hline & & Korejská mise & 4 \\
\hline & & Blízkovýchodní mise & 53 \\
\hline & & Nizozemská mise & 15 \\
\hline & & Norská mise & 3 \\
\hline & & Filipínská mise & 2 \\
\hline & & Polská mise & 162 \\
\hline & & Ukrajinská mise & 6 \\
\hline & & Jugoslávská mise & 138 \\
\hline & & Operační pracovníci v ústředí & 94 \\
\hline & & $\begin{array}{l}\text { Speciální zemědělsko-technický } \\
\text { program Rím }\end{array}$ & 23 \\
\hline & & Program stipendií, Ústředí & 9 \\
\hline & & $\begin{array}{l}\text { Program zaměření na trénink } \\
\text { zdravotních sester, Ústředí }\end{array}$ & 10 \\
\hline & & Program přepravy skotu & 219 \\
\hline & & Celkem & 7989 \\
\hline
\end{tabular}

Vedle tohoto personálu typu Class I. UNRRA přímo na místě působnosti zaměstnávala pracovníky z přijímacích států a ve shromaždištích vytipované obyvatele, tedy samotné DPs [Slatt 2008: 278], patřičně jazykově a odborně vybavené - tzv. Personnel Class II. UNRRA vždy kladla u svých zaměstnanců důraz na určitý smysl pro internacionalismus na úkor národnostního cítění, nově se pracovníci vykreslovali jako mezinárodní dobrovolníci starající se o „Ztracené a opuštěné“ [Salvatici 2012: 437]. Internacionalismus se stal jedním z hlavních myšlenkových pilírư celé organizace. K prosinci roku $194516 \%$ zaměstnanců prvního typu (Class I.) tvořili Američané, 18 \% Francouzi a 31 \% Britové. K červnu 1946 63,7 \% zaměstnanců byli muži a 36,3 \% ženy [Gamie - Humbert 2012: 146]. Více jak polovina všech zaměstnanců měla na starosti program DPs, a to zejména v Německu, o něco méně pak v Rakousku a Itálii. Vedení organizace muselo často čelit obviňování, $\mathrm{v}$ častých př́padech oprávněnému, že se mnohdy do jejich řad hlásili zcela nekompetentní lidé. V první řadě byla na vině hlavně špatná personální politika organizace, chyběl standardizovaný a jednotný proces jak samotného přijímacího řízení uchazečů o pracovní místo, tak i jejich následného zaškolování. Navzdory jasnému faktu, že úspěšnost akce DPs závisela mimo finančního zabezpečení hlavně na vhodném výběru personálu, UNRRA v tomto ohledu selhala, když nedokázala přijít s ucelenou řadou požadavků na 
nově vzniklou pracovní pozici „mezinárodní humanitární pracovník“. Následkem všech těchto problémů a nepřiliš profesionálního začátku bylo působení úředníků a zaměstnanců organizace př́mo v místě působnosti dost nevyrovnané. Zaměstnanci se ve stejných pozicích na různých místech neshodovali v postupech, v cíli, a dokonce ani v samotné definici rehabilitace a pomoci [Salvatici 2012: 429]. Zdá se, že organizace UNRRA hrubě podcenila př́pravu na tento úsek pomoci, a to i navzdory jasné ambici profesionalizace charity na mezinárodní úrovni.

Motto kampaně na přípravu této humanitární akce bylo „help people to help themselves“. Na základě této kampaně se vedly přijímací hovory v USA a Evropě a vybírali se lidé s patřičnou kvalifikací a adekvátními zkušenostmi, aby se stali profesionálními sociálními pracovníky. Motivace lidí vstupujících do řad této nově vzniklé organizace byla různá. Přes čistě altruistické motivy, nadšený idealismus, touhu po cestování a dobrodružství, po přirozené pokračování ve službách armády po skončení bojů (často se rekrutoval armádní personál, od vojáků až po válečné zdravotní sestry) až v neposlední řadě po potřebu jisté prestiže a dosažení určitého společenského statutu. Někteří pracovníci byli motivováni čistě profesně, jelikož se UNRRA snažila vyhnout určitému amatérismu v přístupu k humanitární pomoci a snažila se zavést vědečtější a novější principy a metody v oblasti výživy, průmyslu a zemědělství. $\mathrm{V}$ jejich řadách se tak objevovali nutriční specialisté, zemědělští technici, průmysloví odborníci a zkušení sociální pracovníci. Zejména pro sociální pracovníky byla práce $\mathrm{v}$ organizaci zkušenost $\mathrm{k}$ nezaplacení a mnohdy začátek působivé kariéry. Je známo, že mnoho zdravotních sester, které působily v řádách UNRRA, po skončení této organizace hrály vedoucí úlohy v nově vzniklé WHO (World Health Organization Světová zdravotní organizace) [Gemie - Humbert 2012: 1950]. I finanční odměna za práci byla pro některé hlavním motivem, i když se to nezmiňuje tak často. UNRRA nabízela velmi dobrě placené pozice at’ už v ústředích organizace, nebo přímo na místě působnosti. $Z$ výše řečeného vyplývá, že se do organizace přidávali lidé nejrůznějších profesí, např. bývalí vojáci bez hlubších znalostí z oblasti sociálních prací na jedné straně, na straně druhé významní lidé např. z bankovního či zdravotnického sektoru, kteří za své působení přímo na místě dostávali 4000 až 5000 dolarů za rok. ${ }^{13}$ Rozdílné motivy (at’ už osobní či profesní), země a sociální prostředí, z něhož zaměstnanci do organizace přišli, znamenaly však v praxi na místě i přirozeně naprosto nejednotný přístup, což někdy přinášelo problémy a zpomalovalo práci.

Po prrijetí následoval krátký trénink ve třech různých lokalitách - USA, UK a Francie. Britové měli před odjezdem do Německa krátké školení v Londýně. ${ }^{14} \mathrm{~V}$ USA, v Marylandu za velké osobní podpory Eleanor Rooseveltové bylo zřízeno hlavní školicí středisko pro zaměstnance nabrané zejména v USA, byt’ s rozdílným původem. Od roku 1944 byl hlavním ředitelem tohoto střediska původem český rodák Dr. Frank Munk. ${ }^{15}$ Hned na počátku svého působení se musel vyrovnat s problémem náboru zaměstnanců $\mathrm{z}$ řad rozpuštěných spojeneckých armád. Dr. Munk a spolu s ním i někteří lidé na vyšších pozicích

13 Benjamin Fine [May 21, 1944] Unrra Schools is Training Workers for the Grim Job of Relief in War-Stricken Countries, The New York Times, Page E-11.

14 NA, UNRRA, karton 93, Confidental, Dokumenty k 3. zasedání Rady, č. 9, 1945, Report of the Director General to the Council, for the period 1st April 1945 to the 30th June 1945, s. 61.

15 Frank Munk působil v USA od roku 1939, kdy utekl před nacistickým režimem. Působil jako profesor ekonomie a politických věd na kalifornské univerzitě Berkeley, když přišla nabídka od UNRRA. 
pochybovali o tom, že by se z bývalého vojáka prostoupeného nacionalismem mohl během krátkého tréninkového výcviku stát humanitární pracovník s citem pro principy internacionalismu. Pracovníci se ve školících zařízeních procvičovali v jazyce, historii a kultuře té země, kde měli působit. Jako základní chyba bylo později vnímáno prakticky úplné vynechání či naprosto marginální zmínění o zemích původu těch lidí, kteří do táborů přicházeli. Lidé, kteří takovým školením procházeli, neskrývali své zklamání a nešetřili kritikou.

\section{Organizace akce DP v jednotlivých zemích}

Dle všech smluv a dohod přijatých na zasedání Rady UNRRA se začala organizace angažovat celkem $\mathrm{v}$ pěti oblastech. $\mathrm{V}$ americké, britské a francouzské zóně poválečného Německa, $v$ americké, britské a francouzské zóně poválečného Rakouska, dále v Itálii, na Středním východě a v Číně. Úplně první akcí organizace týkající se této oblasti DP bylo v květnu 1944 převzetí odpovědnosti nad šesti tábory na Středním východě, čítajícími na 40000 uprchlíků, a to především Jugoslávců, Řeků a obyvatel Dodekánských ostrovů. ${ }^{16}$ Velké procento těchto uprchlíků byly ženy a děti, rodiny partyzánů. V Německu se starala organizace pouze o ty osoby, které měly na pomoc nárok dle dohod přijatých na zasedání Rady, celkem to bylo okolo 57,4 procent z celkového počtu „displaced persons“ [Woodbridge 1950: 491]. V Rakousku byly tábory méně početné a v Itálii bylo procento těchto zavlečených lidí $v$ poměru $k$ Německu poměrně nízké. $V$ těchto př́ípadech UNRRA nebyla finančně odpovědná za dodávky. Na Středním východě UNRRA udržovala uprchlické tábory a zajištovala základní dodávky, které narozdíl od Evropy platila z rozpočtu organizace. UNRRA $v$ tomto prŕpadě také platila náklady na repatriace (transfer po moři k Dodekánským ostrovům a dále pak na kontinent do Jugoslávie a Řecka). Rozsáhlá pomoc uprchlíkům probíhala také v Číně, kde obdobný program měla na starosti CNRRA. Po světě, např. v oblasti Středního východu, ve východní Africe, v Indii, byly roztroušeny také malé skupiny Poláků, které byly dle všech přijatých rezolucí oprávněny pro př́ijem pomoci od organizace UNRRA, ale nikdy se jim jí nedostalo. Na místo UNRRA se tak starala o tyto lidi britská vláda, která podporovala shromaždovací centra.

Počet hlavních shromaždovacích center v Evropè ${ }^{17}$

\begin{tabular}{|l|c|c|c|c|c|}
\hline & $\begin{array}{c}\text { Německo- } \\
\text { americká zóna }\end{array}$ & $\begin{array}{c}\text { Německo- } \\
\text { britská zóna }\end{array}$ & $\begin{array}{c}\text { Německo- } \\
\text { franc. zóna }\end{array}$ & Rakousko & Itálie \\
\hline prosinec 1945 & 134 & 78 & 15 & 25 & - \\
\hline červen 1946 & 154 & 98 & 36 & 38 & - \\
\hline prosinec 1946 & 400 & 443 & 78 & 30 & - \\
\hline červen 1947 & 416 & 272 & 45 & 21 & 8 \\
\hline
\end{tabular}

16 NA, UNRRA, karton 53, zahraničně obchodní tisk, The History of UNRRA, s. 86.

17 „Statistics, European Region“, vols. III, IV, V [Woodbridge 1950: 501]. 


\section{Život v centrech}

Pod správou UNRRA byla až do června roku 1946 organizace a struktura ve shromaždištích podřízena plně repatriačním potřebám. Dle toho byly uprchlické tábory strukturovány podle národnosti a občanství18 (tak, aby rodiny byly u sebe). UNRRA se starala o všechny základní potřeby počínaje distribucí potravin, oblečení, zaopatřováním léků až po hygienické potřeby. Ve stravování pracovníci chtěli původně dodržet jimi stanovený limit 2650 kalorií na jeden den pro jednoho člověka, ale nikde se jim to nepodařilo. V reálu se dodržování kalorií nakonec lišilo od regionu k regionu a od osoby k osobě. Byl však kladen velký důraz na dětskou výživu, protože se v letech 1946 až 1947 všechna DP centra v Německu a Rakousku těšila velmi vysoké porodnosti [Comet 2000: 301].

UNRRA kontribuovala také tím, že dohlížela na domácí dodávky jídel, jejich efektivní př́pravu, celkově se starala o to, aby lidé získali, co jim od vojenských a místních politických představitelů dle dohod náleželo. Samotné jídlo pak do center přicházelo z nejrůznějších zdrojů, ty trvanlivější zejména $\mathrm{z}$ armádních skladů a $\mathrm{z}$ lokálních zásob. $\mathrm{V}$ každém centru byl určen pracovník organizace, který měl na starosti každý týden připravit stravovací plán dle různých skupin obyvatel centra a zásob.

UNRRA pomáhala s dodávkami nadstandardního zboží [Woodbridge, Statistic. European Region 1950: 503]

\begin{tabular}{|l|c|c|}
\hline & $\begin{array}{c}\text { Částka } \\
\text { v US dolarech }\end{array}$ & $\begin{array}{c}\text { Hmotnost zboží } \\
\text { (Gross Long Tons) }\end{array}$ \\
\hline Jídlo & 2427500,00 & 5046,00 \\
\hline Oblečení, obuv & 1177700,00 & 1034,00 \\
\hline Léčiva a hygiena & 677700,00 & 789,00 \\
\hline Zemědělská obnova & 37500,00 & 406,00 \\
\hline Průmyslová obnova & 3210800,00 & 5578,00 \\
\hline Celkem & 7531200,00 & 12853,00 \\
\hline
\end{tabular}

$\mathrm{V}$ rámci těchto dodávek distribuovala hlavně cigarety, sladkosti pro děti, mýdla, z oblečení hlavně výbavy pro novorozence a další oblečení pro malé děti. V oblasti dodávek pro průmyslovou obnovu šlo hlavně o vybavení domu, kuchyně. Do této kategorie byly zahrnuty také školní a školicí pomůcky, které sloužily obyvatelům a dětem ve speciálních školicích centrech a učebnách. Co se týče zdravotní péče a prevence, UNRRA hrála velmi důležitou roli a dá se v tomto ohledu říci, že díky její přítomnosti bylo zažehnáno několik epidemií v zárodku. Vojenský zdravotní a hygienický program, jaký byl nastaven

18 V poválečných letech bylo určení národnosti, příslušnosti ke státu a národu dost komplikované, hlavně co se týče obyvatel Sovětského svazu a židovských obyvatel různých států. Židovští přeživší koncentračních táborů museli mnohdy čelit i v DP shromaždištích dalším nepřijemnostem vyplývajícím z antisemitismu, nebot byli mnohdy ubytováni dle stejné přislušnosti ke státu s Němci, Poláky, z nichž se někteří ani po válce nezbavili své nevraživosti vůči Židům. Situace se mírně zlepšila až po zásahu prezidenta Trumana, resp. po zveřejnění Harrisonova reportu, viz kapitola Př́prava a struktura DP akce. 
$\mathrm{v}$ jednotlivých centrech, byl vesměs všude podobný a velice jednoduchý. Všechna centra musela být udržována v čistotě, každý obyvatel prvně prošel odvšivovací kůrou a měl být imunizován proti neštovicím a břišnímu a skvrnitému tyfu, aby se tak předešlo epidemiím. ${ }^{19}$ Během roku 1945 byla tato odpovědnost na armádě, $v$ této době bohužel kvůli trvajícím katastrofálním podmínkám, nedostatku odborné péče a léků lidé $\mathrm{v}$ táborech pořád umírali. Situace se začala pomalu měnit ke konci roku 1945, v průběhu posledních měsícủ tohoto roku přijižděli odborníci z organizace UNRRA - doktoři a sestřičky, kteří postupně přebírali odpovědnost a zdravotní dohled $\mathrm{v}$ centrech. S tímto přebrali zároveň i nastavený a již zaběhlý řád. Pracovníkům se dařilo držet nemoci pod kontrolou. Odborný personál organizace UNRRA připravil preventivní programy, které měly pomoci snížit riziko epidemií zejména v zimním období. Do preventivních zařízení spadá i zřízení a příprava izolačních prostorů, jež měly sloužit $\mathrm{v}$ př́ípadě vypuknutí epidemie nakažlivé nemoci, či př́prava relevantního množství medikace a proočkování obyvatel ve všech centrech.

\section{Zaměstnání v centrech}

Ačkoli otázka zaměstnanosti $\mathrm{v}$ kempech a shromaždištích byla $\mathrm{z}$ velké části pod kontrolou organizace, veškeré práce mimo ně musela být odsouhlasena vojenskými představiteli. Základní politika správy fungovala na jednoduchém principu: veškerá práce měla být dobrovolná a placená, ale zároveň byli lidé hojně motivováni a podporováni se o práci ucházet. Na základě všech zkušeností fungovalo i v těchto shromaždištích pravidlo, čím vyšší zaměstnanost, tím vyšší standard samotných center a spokojenější obyvatelé. Mít práci znamenalo znovuzrození $\mathrm{v}$ „,normální lidskou bytost“, dotyčný přestával být uprchlíkem [Salvatici 2012: 438]. Tento přerod trval často i několik měsíců, přes veškerou euforii $\mathrm{z}$ osvobození přišel krátce poté útlum, muži v centrech neměli zájem pracovat či se nějak aktivně zapojit do jejich chodu, ženy ztrácely mateřský smysl. Apatie prostupovala všemi složkami lidského bytí. Pracovníci organizace tak od začátku po zajištění základních potřeb povzbuzovali obyvatele center, aby se podíleli na každodenním chodu centra, zdravotní sestry povzbuzovaly matky formou různých soutěží $\mathrm{k}$ důkladnějši péči o děti.

Jak už bylo řečeno, veškeré práce $\mathrm{v}$ centrech byla úzce spojena se správným chodem, údržbou a rozvojem centra, obyvatelé zde byli zaměstnáni jako zaměstnanci UNRRA Class II., ale takových pozic bylo jen několik. Bylo tedy nutné hledat práci mimo samotná centra. Vojenské autority jednotlivých zón původně nastavily oficiálně politiku tak, že DP lidé by měli mít přednost před samotnými Němci. ${ }^{20} \mathrm{~V}$ samotné praxi se však tato politika jevila jako těžce realizovatelná. Obyvatelé center měli často nižší kvalifikační a odborné zkušenosti, navíc některé tábory byly umístěny daleko od frekventovaných měst či center populace, kde by se práce nacházela snadněji. Postupem času začali mít také vojenští představitelé a správci zón nevyhnutelně pocit zodpovědnosti také vůči samotným Němcům a Rakušanům. Navzdory všem překážkám se podařilo prakticky nemožné a v některých shromaždištích se míra zaměstnanosti k roku 1947 vyhoupla někdy až k 98 \% všech

19 NA, UNRRA, karton 93, Confidential, Dokumenty k 3. zasedání Rady, č. 9, 1945, Report of the Director General to the Council for the period 1st April 1945 to the 30th June 1945, s. 17.

20 SHAEF Administrative memo 39, Appendix D, „Employment of Displaced Persons in Germany“, revised 16 April 1945 [Woodbridge 1950: 518]. 
práceschopných. Průměrně napříć Německem se pak udržovala míra zaměstnanosti okolo 70 \% (některá centra si udržovala vyšší míru díky své geografické poloze, jiná zase menší).

\section{Role organizace UNRRA v programu DP}

Součástí práce UNRRA pracovníků byl mimo jiné i dohled nad vzděláváním a odbornými tréninkovými programy a rozvoj sociální péče a odpočinkových aktivit. Bez dlouhého plánování byly založeny téměř $\mathrm{v}$ každém centru základní a někde i střední školy. Vyškolení učitelé jezdili mezi tábory, texty opisovali sami, učebnice se připravovaly nárazově dle potřeby. UNRRA pomáhala se samotnou organizací všech těchto školek a škol, kde také pod její záštitou probíhaly speciální vyživovací programy. Uprchlíci mezi sebou také začali vybírat schopné jedince, kteří po zaškolení zastávali posty učitelů a správců jednotlivých škol. Starším studentům z řad DPs, jejichž předchozí vzdělání bylo přerušeno válkou, německé univerzity rezervovaly $10 \%$ volných míst. Největši zájem byl tradičně o studium medicíny. Upřednostňovali se ti studenti, kteří studium před válkou měli již v pokročilejší fázi. Jim byla zaopatřena veškerá péče od vojenské správy dané zóny za administrativní pomoci UNRRA. ${ }^{21}$ Samotní uprchlíci s pomocí kanadských pracovníků organizace dokonce založili jednu univerzitu se sídlem v Mnichově (UNRRA University). Univerzita sídlila přímo $\mathrm{v}$ centru města ve vědeckotechnickém muzeu. Výuka začala již po létě v roce 1945 a zaměřila se prvně pouze na výuku jazyků $v$ podobě schůzek intelektuálně zaměřených obyvatel DPs center spiše než v podobě organizovaného přednášení. Oficiálně byla prohlášena za univerzitu až $\mathrm{v}$ únoru následujícího roku. $\mathrm{V}$ době největší popularity měla až na 2000 studentů [Holian 2008: 168]. UNRRA prvně univerzitu podporovala, ale jen do doby, kdy bylo po vnějším tlaku na vyšších místech organizace v Londýně rozhodnuto, že se jednalo o "antirepatriační" aktivitu [Woodbridge 1950: 525], tzv. akt permanence, což nebylo primárním úkolem organizace $\mathrm{v}$ zajištování uprchlíků. Bylo dále př́sně nařízeno z ústředního štábu organizace, aby se zaměstnanci zdržovali jakýchkoli podobných aktivit, na které se hledělo jako na překročení pravomocí terénních pracovníkủ [Armstrong Reid Murray 2008: 171]. Hlavním úkolem mělo zůstávat zajištění repatriace a př́ípadné školení či trénink, který měl napomoci v zemi původu se rychleji dostat do procesu poválečné obnovy. Časově kratší workshopy tak dostávaly podporu, jako tomu bylo např. u tzv. Baltského studijního centra se sídlem v Hamburku, které dostalo schválení vedení organizace a veškerou pomoc od britských představitelů okupační zóny.

Prakticky ve všech centrech organizovala UNRRA odborné programy, školení a workshopy, vedla specializované školicí stř̌ediska, do kterých mohli chodit jedinci ze všech shromaždovacích center. Školicí střediska v centrech byla většinou zaměřená na profese jako krejčí, výrobci obuvi, různí opraváŕi, tesaři, specialisté na radiová a telegrafní zařízení apod. UNRRA zajištovala instruktory, školicí materiály, pomůcky, ale i stroje, na kterých mohli jedinci práci trénovat. Ve venkovních školicích centrech se lidé mohli účastnit dlouhodobých či krátkodobých kurzů se specializací na řízení nákladních vozidel, na údržbu a správu železnic, navigaci, mohli si vybrat i specializaci námořní odborník.

21 NA, UNRRA, karton č. 56, svazek Zahraniční obchodní tisk, inv. č. 119, Report of the Director General to the Council for the period 1st October 1945 to 31st December, Washington DC, 1946, s. 35. 
Podobně byly také ustanoveny doplňující kurzy a tréninky vedené odborníky pro zdravotní sestry a doktory, kteří díky válce ztratili kontinuitu ve své profesi.

Vedle podpory vzdělání a zaškolování UNRRA dbala v táborech také na rekreační složku každodenního života. Podporovala obyvatele center ve sportu a umění. Skoro v každém centru se nacházel malý divadelní soubor, složený opět z dobrovolníků z řad obyvatel. V některých centrech se nacházelo tehdy velmi oblíbené kino. Co se týče sportu, velmi populární byl fotbal, box a plavání, pro které byly ve vybraných centrech vybudovány malé plavecké bazény. Lidé pořádali soutěže mezi jednotlivými centry, byla také organizována fotbalová liga. Ǔčast na podobných aktivitách fungovala obdobně jako aktivní účast na chodu center, lidem pomáhala na moment se oprostit od tragické minulosti a žít alespoň chvíli znovu normální život. UNRRA se také zapojila do pátrání po ztracených osobách. $\mathrm{K}$ tomuto účelu byl zř́zen Centrální pátrací úřad - Central Tracing Bureau při hlavním velitelství organizace UNRRA, který měl pomoci ke znovuobnovení zpřetrhaných rodinných či prátelských vztahů [Woodbridge 1950: 529].22

\section{Repatriace a přesídlení}

Samotné repatriace těchto lidí více než na samotné organizaci záviselo ze začátku (během roku 1945 a na počátku roku 1946) spíše na činnosti jednotlivých vlád, které musely připravit nějaký plán a schválit návrat či imigraci DPs. Pomoc organizace v této oblasti spočívala ze začátku pouze $\mathrm{v}$ administrativním a technickém zázemí plánovaných akcí. Neschopnost předání či alespoň sdílení pravomocí spočívalo především v nejasnosti, která osoba přesně má být repatriována a která přesídlena. Př́kladem může být např. skupina uprchlíků - emigrantů, kteří až s blížícím koncem války či dokonce po válce utekli ze zemí jako Polsko, Jugoslávie, Bulharsko, Madarsko, Rumunsko. Směřovali do Německa, Rakouska či Itálie, kde se snažili uplatnit nároky vyplývající ze statutu DPs. Z větší části se jednalo o Židy, se kterými UNRRA sympatizovala, avšak dle všech rezolucí a dohod byla organizace autorizována pomoci pouze př́slušníkům státu OSN, kteří byli přemístěni v průběhu války, nebo př́slušníkủm bývalých nepřátelských států, kteří byli ve své vlasti nepřítelem perzekuováni. Ani jeden těchto statutů nepasoval na poválečné uprchlíky. Rada organizace se dodatečně rozhodla zařadit všechny Židy bez rozdílu do skupiny mající automaticky nárok na pomoc. Samozřejmě, pokud se nezjistily závažné důvody, pro které by byla pomoc nelegitimní [Kochavi 2001: 140]. Tak byl vyřešen problém Židů, zbývající museli dokázat, že byli během války diskriminováni či vnitřně (tzn. na území své vlasti) pronásledováni. Dalším zjevným problémem, který se musel řešit až za běhu, byli lidé, kteří byli již jednou repatriováni (především Poláci), ale rozhodli se opět vrátit do Německa (v menší míře do Rakouska) a žádat znovu o statut DPs. V těchto případech se rozhodlo, že ten, kdo se již jednou vrátil do země původu, nebude považován již dále za osobu legitimní obdržet pomoc od organizace UNRRA. Ačkoli veškerá pravidla byla nastavena, UNRRA

${ }^{22}$ K obnově komunikace mezi ztracenými rodinnými př́slušníky či práteli UNRRA podnikla nespočet pátracích akcí, kdy např́iklad jen v listopadu roku 1945 bylo předloženo organizaci 29495 žádostí o pomoc při pátrání po určité osobě. $\mathrm{V}$ dubnu roku 1946 již obdržela přes 100000 žádostí a v tom samém měsíci a následujícím květnu bylo vyř́izeno okolo 53000 žádostí. NA, UNRRA, karton 56, Zahraniční obchodní tisk, inv. č. 119, Report of the Director General to the Council for the period 1st April to 30th June 1946, s. 37. 
se snažila každý př́pad krátce projednat individuálně před přijetím či odmítnutím do centra. Před počátkem repatriačních akci se opět muselo posuzovat, kdo bude repatriován a kdo ne. Samotné vedení organizace si uvědomovalo plně následky dlouhodobého pobytu v uprchlických táborech na duši člověka i na jeho schopnosti. Bylo naprosto zřejmé, že lidé budou více užiteční $\mathrm{v}$ zemích svého původu a plně tak byly podporovány repatriace lidí, kteří primárně nebyli v žádném konfliktu s vládou své vlasti. A stejně tak jako organizace i vlády samotné usilovaly o co nejrychlejší návrat těchto lidí. Tyto repatriace se organizovaly lehce a byly více méně jen otázkou času a peněz na transport. Velká část uprchlíků, bývalých vězňủ koncentračních táborů a nuceně nasazených, se tak díky této pomoci vrátilo hned v prvních měsících po osvobození. Uvádí se, že do podzimu 1945 se jen z Německa úspěšně navrátilo přes pět miliónů všech spadajících do kategorie DPs. A ve sledu následných pěti měsíců bylo připraveno na návrat dalších více jak 300 tisíc lidí. ${ }^{23}$ Následně však tento trend rapidně klesl. Příčina se jevila na jedné straně v nevyřešených národnostních, politických, náboženských a (u některých) i osobních problémech, na straně druhé pak stála uvědomělá možnost jasnější a lepší budoucnosti v jiné zemi než v zemi původu. Vše bylo navíc do jisté míry zkresleno různými zdroji informací z těchto zemí. Motivy skrývající se za neochotou být repatriován u většiny lidí pobaltských národů, Poláků a Jugoslávců byly víceméně politické, u lidí židovského původu převládal strach z perzekuace. Naopak mezi národy, kde prakticky nebyl větší problém s repatriací, se mohli počítat Francouzi, Lucemburčané, Belgičané, lidé ze Skandinávie a Dánové, obdobně hladce, byt’ s občasnými výjimkami, proběhly repatriace u Čechoslováků, Řeků a Italů. ${ }^{24}$

V polovině roku 1946 skupinu neochotných $\mathrm{k}$ repatriaci jenom v Německu tvořili Židé (50 000), Baltové (180 000), Sověti (6000), Jugoslávci (24 000), skupina neidentifikovatelných a mix různých dalších národů $(60000)$ a navíc ještě Poláci, kteří byli rozdrobeni napříc Německem a jejichž množství se v roce pohybovalo odhadem okolo 300 tisíc, ale u kterých se stále ještě doufalo, že většina z nich bude do konce roku 1946 ochotna býti repatriována. ${ }^{25}$

Tím, jak vzrůstala neochota „tvrdého jádra“ lidí k repatriacím v druhé polovině roku 1946, tím více narůstal tlak představitelů okupačních správ na zaměstnance UNRRA tento problém řešit. Ve stejné době se konala řada konferencí na toto téma. Organizace se musela okamžitě zbavit všech svých pracovníků, kteří podporovali a zastávali se z různých důvodů lidí, kteří repatriacím vzdorovali. $V$ centrech se začala vydávat a šírit periodika, nejprve od UNRRA, posléze i periodika z původních zemí, které měly za úkol podporovat repatriace. A naopak bylo důsledně zakázáno šíření těch period, které se jevily jako opoziční k ustanoveným vládám $\mathrm{v}$ původních zemích repatriantů.

Navzdory všem snahám ale repatriace $\mathrm{v}$ druhé polovině roku 1946 prakticky ustaly. Bylo čím dále více zřejmé, že pro tyto lidi repatriace není možným řešením. Začalo se uvažovat o přesídlovacím programu. $Z$ počátku oslovené státy reagovaly s nezájmem, v pozdějším čase se ale otázka rrízené migrace práceschopných do průmyslově

\footnotetext{
23 NA, UNRRA, karton 53, zahraniční obchodní tisk, The History of UNRRA, s. 42.

24 NA, UNRRA, karton 56, inv. č. 119, zahraničně obchodní tisk, Report of the Director General to the Council for the period 1st April to 30th June 1946, s. 36.

25 Tamtéž, s. 33.
} 
silných regionů začala pomalu řešit. Zájem byl také o ženy, které by pracovaly v sociální sféře jako pečovatelky a pomocné síly $\mathrm{v}$ nemocnicích. ${ }^{26} \mathrm{~V}$ průběhu roku 1947 se začalo s protahovaným přemístováním osob. Z britské zóny bylo již $\mathrm{v}$ dubnu 1947 přemístěno 13385 obyvatel center DPs do Velké Británie v rámci zaměstnaneckého programu (Westward Ho program), který se posléze vztahoval i na obyvatele center DPs v britské zóně Rakouska. Podobným směrem šla i Belgie, která se zavázala přijmout okolo 15 tisíc lidí z americké a 20 tisíc z britské okupační zóny (do konce prvního čtvrtletí do Belgie odcestovalo 13200 lidí z americké zóny) a Francie, která přijala v prvním čtvrtletí 1400 lidí z americké zóny, navíc francouzská vláda ohlásila plán přijmout až na 50 tisíc lidí jako budoucí zaměstnance a dělníky. Menší počty lidí odešly na jaře 1947 do Brazílie, která také projevila zájem o nerepatriované uprchlíky. UNRRA a v závaznosti na ni IRO zahájila obdobná jednání se zeměmi, jako je Kanada, Nizozemí, Norsko, Argentina, Venezuela o přijetí zbylých obyvatel těchto center. ${ }^{27}$ Spojené státy přijaly za silné podpory prezidenta Trumana v roce 1948 tzv. Displaced Persons Act, který umožňoval trvalý pobyt vybraným obyvatelům DPs center. Naopak některé země se stavěly vysloveně negativně k jakémukoli dlouhodobějšímu pobytu, mezi ně patřilo i Československo, které provádělo naprosto nejzákladnější úkony, aby vyšlo vstříc Misi organizace v ČSR a jejím zástupcům. ${ }^{28}$

\section{Závěr}

K prvnímu červenci roku 1947 se dle výše zmíněné rezoluce č. 99 převáděla veškerá odpovědnost na Mezinárodní organizaci pro uprchlíky - IRO, resp. prozatím na její př́ípravný orgán, protože formální zřízení organizace vázlo na signatuře několika států. Organizace UNRRA tak existovala jen několik roků a i když se s její dočasností počítalo hned od počátku, přece jen konec v roce 1947 překvapil mnohé. Její existence přesně korespondovala s intervalem mezi koncem druhé světové války a počátkem studené války. Někteří historici jako např. Jessica Reinisch, která se dlouhodobě zabývá organizací UNRRA, v tom nevidí náhodu [Reinisch 2011,2013]..$^{29}$ Do určité míry je načasování př́íznačné. $V$ roce 1947 se dostávaly pomalu některé státy, které přispívaly na pomoc v rámci organizace, do horší situace než země pomoc přijímací. To byla neudržitelná situace. Otázkou k diskuzi byla úspěšnost celé organizace. $\mathrm{V}$ dobových materiálech se štědrost organizace v programech rehabilitace dost přeceňovala. Co se týče akce DPs, je sporné, jestli se lze bavit o úspěchu, kterým bezesporu je rychlé znovuzačlenění obyvatel center do normálního života se všemi aspekty zdravotní a sociální rehabilitace, pokud se vezmou v potaz ohromné finanční výdaje, které na akci byly použity. Stejně tak se ozývala i kritika nerovnoměrné finanční politiky organizace vůči státům severozápadní Evropy v poměru ke státům Evropy stř̌edovýchodní, kde UNRRA přes veškerou snahu prohrávala v této

26 NA, UNRRA, karton 53, zahraniční obchodní tisk, Parliamentary debates, House of Common, official report, 28th Jan 1947, s. 9.

27 NA, UNRRA, karton 56, inv. č. 119, zahraničně obchodní tisk, The Report of the Director General to the Council for the period 1st April to 30th July 1947, s. 28

28 NA, UNRRA, karton 66, složka druhá - Repatriace osob 1946, dokumenty jako zpráva z Ministerstva zahr. věcí o smlouvě mezi ČSR a UNRRA o zřizování táborů pro DP, či zpráva ze 12. 12. 1946 z porady na MZV týkající se polských uprchlíků.

29 Reinisch, Jessica [2013]. Auntie „UNRRA“ at the Crossroads. Past and Present, Suppl. 8, či Reinisch Jessica [2011]. Internationalism in Relief: The Birth (and Death) of UNRRA. Past and Present, Suppl. 6. 
době jistý pokus o politické ústupky výměnou za zboží a obnovu v rámci programu [Sharp 2012]. Naopak se zdálo, že komunistické vlády v zemích, kde působila Mise UNRRA, často zneužívaly zásilky k upevnění své moci a k očernění organizace. V roce 1947, v počátcích studené války, přestával být výše zmiňovaný internacionalismus spolu s určitým kulturním relativismem potřebným k práci sociálního pracovníka dále „potřebný“. Politické klima se naprosto změnilo a pracovníci se dostali na rozcestí. V tomto ohledu nastala pro ně deziluze. Přestával se zdůrazňovat mezinárodní kontext celé organizace a naopak se začaly zdůrazňovat Spojené státy coby největší sponzor celé organizace. A to doslova na obou stranách. Americká veřejnost čím dál tím více narážela na fakt, že peníze v rámci organizace jdou často do států, jejichž političtí představitelé se k USA chovají neprrátelsky. Komunistická strana si uvědomovala význam a důležitost pomoci, stejně jako vděčnost obyvatelstva za tuto pomoc. Proto se občas objevovaly snahy program UNRRA bagatelizovat, či naopak ukázat, že pomoc UNRRA pochází hlavně ze Sovětského svazu a nikoliv $\mathrm{z}$ mezinárodních zdrojů v čele $\mathrm{s}$ USA. Vedení UNRRA muselo čím dál více obhajovat svoji práci a vysvětlovat narůstající náklady, přes veškerou snahu se jim však dostávalo menší a menší podpory. $V$ této atmosféře a počátku bipolárního rozdělení světa, které se čím dál tím více projevovalo i při samotných zasedáních Rady, UNRRA končí a předává kompetence nově vytvořeným organizacím pod záštitou OSN. ${ }^{30}$

\title{
Archivní prameny
}

\author{
Národní Archiv - Fondy \\ UNRRA \\ Ministerstvo hospodářské obnovy \\ Ministerstvo zahraničních věcí - výstřižkový archiv \\ Österreichisches Staatsarchiv Wien \\ Složka - UNRRA - Allgemeines, Organization, Aufbau - Statistiker \\ UN Archives in New York \\ fond UNRRA \\ Publikované dokumenty
}

UNRRA a země Moravskoslezská [1947]. Brno: Čs. úřad pro hospodářskou pomoc a obnovu.

UNRRA v ČSR - Sborník o činnosti UNRRA [1948]. Praha: Zaměstnanci čs. Úřadu pro hospodářskou pomoc a obnovu.

Munk, Frank. [1993]. My Century and My Many Lives, An International Civil Servant, publ. Online Theragens.com. Dostupné z: <http://www.theragens.com/MunkBio/Munk_Autobiography_15.htm> [3. 3. 2017].

Von Oppen, Beate Ruhm [1955]. Documents on Germany under Occupation, 1945-1954. London: Oxford University Press.

Germany, 1947-1949; The Story in Documents [1950]. Washington DC: US Dept. of State.

$<$ https://history.state.gov/historicaldocuments> [15. 1. 2017] - Foreign Relations of the United States, publikované dokumenty z politických a diplomatických jednání vztahujících se k zahraniční politice USA.

<http://www.presidency.ucsb.edu/index.php> [15. 11. 2016] - Publikované dokumenty a veřejné vystoupení jednotlivých amerických prezidentů.

30 Vedle IRO to byla zejména také WHO, ECOSOC, FAO a UNICEF, viz např. NA, UNRRA, karton 84, složka koordinační oddělení - Mezinárodní dětský fond. 
$<$ http://library.columbia.edu/locations/rbml/units/lehman.html> [26. 11. 2016] - Publikované dokumenty a korespondence Herberta H. Lehmana - generálního ředitele organizace UNRRA.

$<$ https://www.ushmm.org/exhibition/displaced-persons/resourc1.htm> [5. 12. 2016] - Dokumenty k holokaustu na stránkách Muzea holokaustu.

\section{Literatura}

Armstrong-Reid, Susan - Murray, David [2008]. Armies of Peace, Canada and UNRRA Years. Toronto: University of Toronto.

Cohen, Daniel Gerard [2011]. In War's Wake: Europe's Displaced Persons in the Postwar Order. Oxford: Oxford University Press.

Comet, Theodore [2000]. Life Reborn in the Displaced Persons Camps (1945-1951). Journal of Jewish Communal Service 76 (4): 299-303.

Doherty, Muriel [2000]. Letter from Belsen 1945: An Australian Nurse's Experiences with the Survivors of War. Allen\&Unwin St. Leonards N. S. W.

Gemie, Sharif - Reid, Fiona - Humbert, Laurie [2012]. Outcast Europe, Refugees and Relief Workers in an Era of Total War 1936-1948. Norfolk.

Grossmann, Atina [2011]. Grams, Calories, and Food: Languages of Victimization, Entitlement, and Human Rights in Occupied Germany, 1945-1949. Central European History 44: 118-148.

Haushofer, Lisa [2006]. The „Contaminating Agent“ UNRRA, Displaced Persons, and Venereal Disease in Germany, 1945-1947. Am J Public Health 100 (6): 993-1003.

Hilton, Ella E. Schneider - Hilton, Angela K. [2006]. Displaced Person: A Girl's Life in Russia, Germany, and America. Lousiana: LSU Press.

Herring Jr., George C. [1973]. Aid to Russia, 1941-1946: Strategy, Diplomacy, The Origin of the Cold War. New York: Columbia University Press.

Holian, Anna [2008]. Displacement and the Post-war Reconstruction of Education: Displaced Persons at the UNRRA University of Munich, 1945-1948. Contemporary European History 17 (2):167-195.

Klemperer, Victor [2000, 2004]. I Will Bear Witness (1933 to 1941), To The Bitter End (1942 to 1945) and The Lesser Evil (1945 to 1959). London: Phoenix.

Kochavi, Arieh, J. [2001]. Post-Holocaust Politics, Britain, The United States, \& Jewish Refugees, 1945-1948. New York: University of North Carolina Press.

Kossert, Andreas [2009]. Kalte Heimat. München: Pantheon.

Kuklík, Jan [2002]. Mýtus a realita tzv. Benešových dekretů. Praha: Linde.

Mainuš, František [1974]. Totálně nasazení (1939-1945). Praha: Mladá fronta.

Mankowitz, Zeev W. [2002]. Life between Memory and Hope: The Survivors of the Holocaust in Occupied Germany. Cambridge: Cambridge University Press.

Reinisch, Jessica [2011]. Internationalism in Relief: The Birth (and Death) of UNRRA. Past and Present 210 (6): 258-289.

Reinisch, Jessica [2013]. Auntie „UNRRA“ at the Crossroads. Past and Present 218 (8): 70-97.

Salvatici, Silvia [2012]. „Help the People to Help Themselves“ UNRRA relief Workers and European Displaced Persons. Journal of Refugee Studies 25 (3): 429-451.

Seipp, Adam R. [2013]. Strangers in the Wild Place: Refugees, Americans, and a German Town, 1945-1952. Indiana: Indiana University Press, Bloominghton.

Sharp, Charles Wesley [2012]. The Origin of United Nation Relief and Rehabilitation Administration, 1939-1943. Pennsylvania: University of Pennsylvania.

Slatt, E. Vincent [2002]. Nowhere to Go: Displaced Persons in Post-V-E- Day in Germany. Historian 64 (2): 275-294.

Sommer, Karel [1993]. UNRRA a Československo. Opava: SÚ AV AČ.

Vaculík, Jaroslav [2002]. Poválečná reemigrace a usídlování zahraničních krajanů. Brno: MU.

Woodbridge, George [1950]. UNRRA: The History of the United Nations Relief and Rehabilitation Administration. New York: Columbia University Press. 
Jana Frydryšková Yasin je studentkou doktorského studia na na Ústavu hospodářských a sociálních dèjin FF UK. V rámci magisterského a posléze doktorandského studia se zabývala předevšim problematikou zahraničních hospodářských programů směrujících do Československa a střední Evropy po druhé svètové válce v rámci hospodářské obnovy zemè. $V$ doktorandském studiu se dỉkladněji zaměruje i na politicko-diplomatické pozadí těchto rehabilitačních programů a nakolik jejich př́tomnost ovlivňovala politickou kulturu. 